\title{
Securitization of Interethnic and Interfaith Relations: West and East European Public Perceptions Compared
}

\author{
Yantsislav Yanakiev, \\ Defense Advanced Research Institute (DARI) at G. S. National Defense College \\ yanakiev@pims.org
}

\begin{abstract}
This paper presents a comparative study of public perceptions of Muslim communities and immigrants in selected West, Central and Southeast European countries based on Eurobarometer and European Values Study data over 2001 - 2015. The analysis reveals some indicators of a process of securitization of interethnic and interfaith relations. The problem is that this process affects successful diversity management policy implementation in contemporary European societies. This situation calls for the implementation of innovative public policies in response to different sources of ethnocultural diversity in the present-day societies.
\end{abstract}

Keywords: immigrants, securitization, multiculturalism, diversity management

\section{The problem: Securitization of Interethnic and Interreligious Relations}

The topic of improvement of dialogue between different religious, cultural and ethnic communities in Europe, and the need for better mutual understanding between the people belonging to these communities, is of particular relevance in the context of the processes of globalization, extensive migration and the need of strengthening stability in the Southeastern Europe. Along with the classic dimensions of interethnic and interreligious relations in the Balkans in terms of traditional minorities and majority, the aspect of so-called "new minorities" emerged as a result of the ongoing migration processes. If the presence of immigrants in the Western Europe has been a long-lasting tradition, it is for Bulgaria and for the Balkans a new situation that presents a number of challenges. 
The analysis of public opinion in the Western Europe since the terrorist attacks in the U.S. on September $11^{\text {th }}, 2001$ and after the violence in London on July $7^{\text {th }}, 2005$ shows that relationships between the Muslim immigrant communities, on the one hand, and the host societies, on the other hand, are increasingly perceived as a security issue.

Regarding the Balkans, usually relationships between the majority and minority groups are perceived as a matter of national security. Moreover, interethnic relations are often seen as a "zero-sum game" in which everything which is in favor of a minority is perceived as a threat to the majority (Kymlicka, 2002). Furthermore, there is widespread prejudice in some of the Balkan societies that minorities are disloyal to the state and that they play the role of a "fifth column" of the neighboring country. The geographical proximity of an alternative homeland for some of the local minority groups is an important factor in this respect (Roudometof, 2002). These facts have been interpreted by some authors as indicators of the process of securitization of interethnic and interreligious relations (Thorsten \& Thorsten, 2007; Zuhal, 2007; Roe, 2004; Cesari, 2009; Cesari et. al., 2006; Vékony, 2014).

The term "securitization" was introduced by the researchers from the Copenhagen School of Security Studies to define a situation in which a fact/process or phenomenon in the public life is presented as an existential threat to the survival, self-determination of individuals and the core values of the society. Accordingly, the public interprets this theme as a security problem and any action outside the normal policy can easily be justified (Buzan \& Wæver, 2003). For that reason, treatment of minorities, no matter traditional or new, largely becomes a security problem rather than an element of social democratic policy.

Under these conditions, the effectiveness of the model of immigrant multiculturalism, which has long been portrayed as a successful form of social integration of minorities in the Western Europe, was challenged because explicitly the process of desecuritization of interethnic relations was defined as one of the most important factors for successful implementation of public policies for managing ethnic and cultural diversity in the Western world (Kymlicka, 2004; Lesińska, 2014; Rex and Singh, 2003).

In short, the issue of management of ethnocultural diversity under the conditions of securitization of interethnic and interreligious relations has a high academic and political importance for Europe because it is directly related to the stability and prosperity of multiethnic and multicultural societies. The development of the securitization process is a challenge for the effective implementation of public policies in response to ethnic and cultural diversity. 
In this paper, the concept of securitization of interethnic and interreligious relations is operationalized based on public perceptions of immigrants and Muslim communities in Europe as a threat to survival, self-determination and the fundamental values of society. For that purpose, the report presents and analyzes data from international comparative public opinion surveys such as Eurobarometer and European Values Study.

Trends in public perceptions of immigrants and Muslim communities in Europe after 2001

The first one since the terrorist attacks of September $11^{\text {th }}, 2001$ Eurobarometer survey found out that nearly 70 percent of the West Europeans more or less supported the statement "Further the 9/11 attacks, one can understand some distrust toward the Muslim community in Europe". Risk perception of international terrorism certainly raised some fears and mistrust of Muslims who live on the continent (Fig. 1).

0\% 10\%20\%30\%40\%50\%60\%70\%80\%90\%100\%

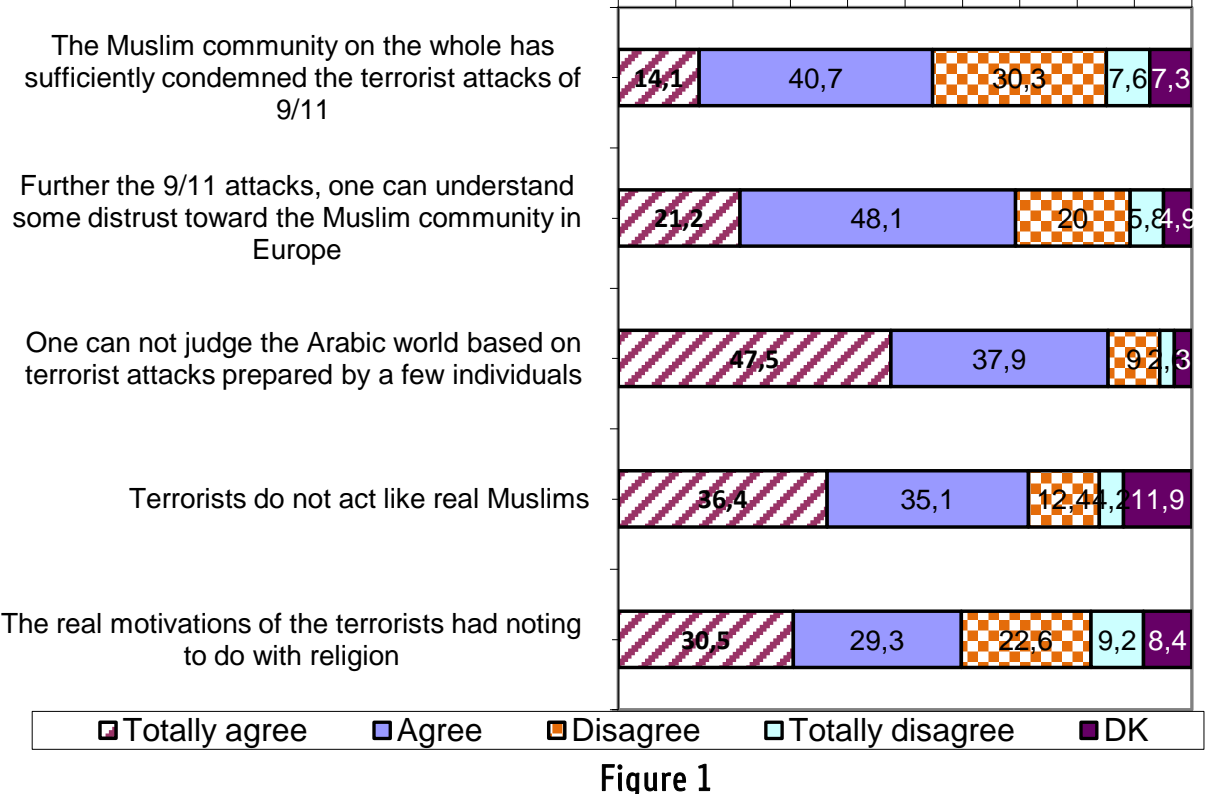

Attitudes towards Muslim communities in Europe, in percent (Source: Flash EB 114, November 2001) 


\section{Secururity}

At the same time, the data analysis shows that West European public opinion was not ready to condemn the Arab and Muslim communities as a whole for the terrorist attacks and did not connect directly Muslims with terrorism. Indicative in this respect is the high degree of agreement ("Completely agree" and "Tend to agree") with the statements such as: "One cannot judge the Arabic world based on terrorist attacks prepared by a few individuals" (85.4\%), "Terrorists do not act like real Muslims" (71.5\%). In addition, majority of the West Europeans in 2001 also supported the statement "The real motivations of the terrorists have nothing to do with religion" (59.8\%). The public was divided regarding the statement "The Muslim community, on the whole, has sufficiently condemned the terrorist attacks of $9 / 11$. Less than $15 \%$ of the respondents completely agree with this statement and $40.7 \%$ tend to agree.

The data analysis from another Eurobarometer survey conducted in 2003 among citizens of the Western Europe shows relatively tolerant attitudes towards immigrants, as it is decisive for whether they are legally residing in the country (Fig. 2). 


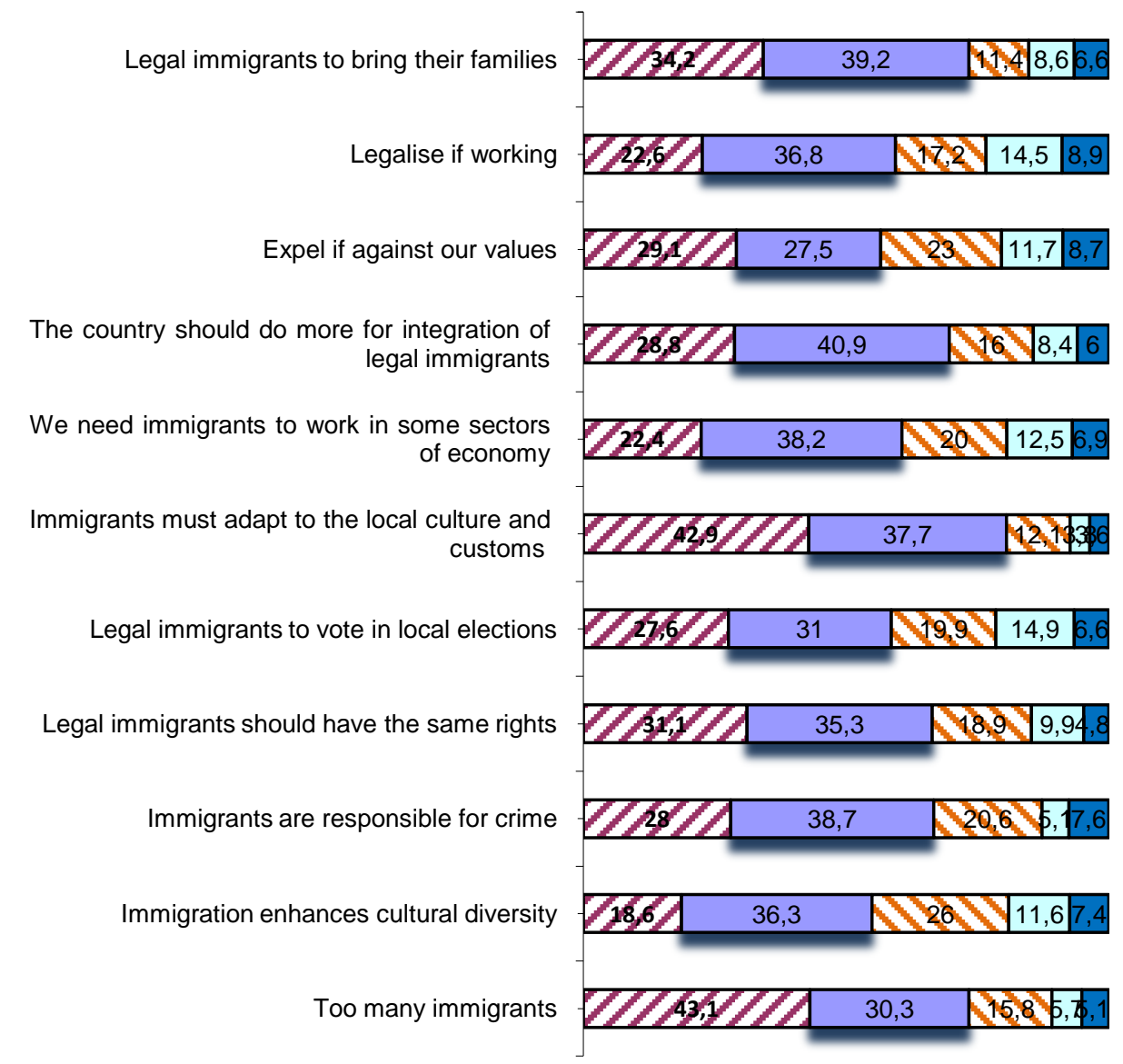

$\square$ Completely agree $\square$ Tend to agree $\square$ Tend to disagree $\square$ Completely disagree $\square \mathrm{DK}$

Figure 2

Attitudes towards immigrants, in percent (Source: EB 59.2 May-June 2003)

Telling in this respect is the prevalent support ("Completely agree" and "Tend to agree") to statements such as "Legal immigrants to bring their families" (73.4\%), "Immigrants to be legalized if they work" (59.4\%), "Legal immigrants should have the same rights as other citizens" (57.6\%), "Legal immigrants to have the right to vote" (58.6\%) and "Immigration enhances cultural diversity" (54, 9\%). 
Understandably, the West Europeans appreciate that in a situation of an aging population, immigration is a "necessary evil" to stabilize and develop the economy, as evidenced by the fact that nearly a quarter (22.4\%) fully agree with the statement "We need immigrants to work in some sectors of the economy". Another $38.2 \%$ of the respondents tend to agree with this statement.

At the same time, West European public opinion recognizes the need of extra efforts for societal integration of immigrants, proved by the strong support ("Completely agree" and "Tend to agree") to the statements "The country should do more for integration of legal immigrants" (69.7\%) and "Immigrants must adapt to the local culture and customs" (79.6\%). Obviously, people understand that this is a bilateral process, which is responsibility of both the host society and the immigrants themselves.

In the face of comparatively tolerant attitudes towards immigrants in the Western Europe at the beginning of the XXI century, the analysis of the data reveals as well certain indicators of securitization of public perceptions. It is characteristic the high degree of agreement ("Completely agree" and "Tend to agree") with the statements "There are too many immigrants in the country" (73.4\%) and "Immigrants are responsible for increasing crime" (66.7\%). More or less the majority of respondents also agree with the statement "Immigrants to be expelled if against our values" (56.6\%).

To sum up, the analysis of the data from quoted Eurobarometer surveys identifies some prejudices and stereotypes in the minds of the West European citizens regarding Muslim communities and immigrants, related to the perception of these groups of people as a threat to survival, self-determination and the fundamental values of society. These facts can be seen as warning signs of the process of securitization of interethnic and interreligious relation in the Western Europe.

How is this process evolving in the coming years? How the outlined fears, stereotypes and prejudices are stable over time? Are there significant differences in public perceptions in the Western, Central and Eastern Europe? Answers to these questions can be found in the second part of the report. Figures 3 and 4 illustrate data on perceptions of immigrants in several selected countries in the Western, Central and South Eastern Europe. The data are from the European Values Study, conducted in 2011. Certain negative statements about immigrants are presented, making it possible to measure stereotypes and prejudices in the European public opinion. 
Both charts represent arithmetic mean values for any statement, measured on a 10 -point scale. The lack of support of the statement is marked by 10 on the scale, while the full agreement with it is marked by 1 . The figures on the scale between 1 and 5 indicate different levels of agreement with the statement. The figures above 5 indicate different levels of disagreement.

The analysis of the data presented in Figure 3 shows comparatively wide-spread stereotypes and prejudices regarding immigrants in the West and Central European societies. This conclusion is supported by the high level of agreement with statements like "Immigrants living in the country are too many", "Immigrants will become a threat to society", "Immigrants are strain on welfare system", "Immigrants increase criminal problems" and "Immigrants take away jobs". Indicative in this regard is the fact that almost all arithmetic mean values are below or close to 5.0. There is relatively less marked agreement with statements as "Immigrants undermine country's cultural life" and "Immigrants maintain own/take over customs", although the arithmetic mean scores are below or close to 6.0. These results can be interpreted as an indication of process of securitization of interethnic and interreligious relations in the Western and Central Europe.

While public opinion is almost unanimous with respect to negative perception of the growing number of immigrants in Europe, on some of the other indicators there are significant differences across the countries represented in the study. The stereotypes about immigrants as a source of crime are strongest in Austria, Germany, Hungary and Italy.

With regard to the fear that immigrants will take over jobs, the analysis shows highest level of prejudice in Hungary, Germany, Austria and the Czech Republic. Similar is the picture when the perception of threat to welfare system is analyzed. Most worried are people in Great Britain, Germany, Austria and Hungary. Finally, the general perception that immigrants will become a threat to society is strongest among the people in the Great Britain, followed by Hungarians, Germans, Czechs, Austrians and Belgians.

In general, public opinion in France and Poland seems to be comparatively more tolerant towards immigrants. 


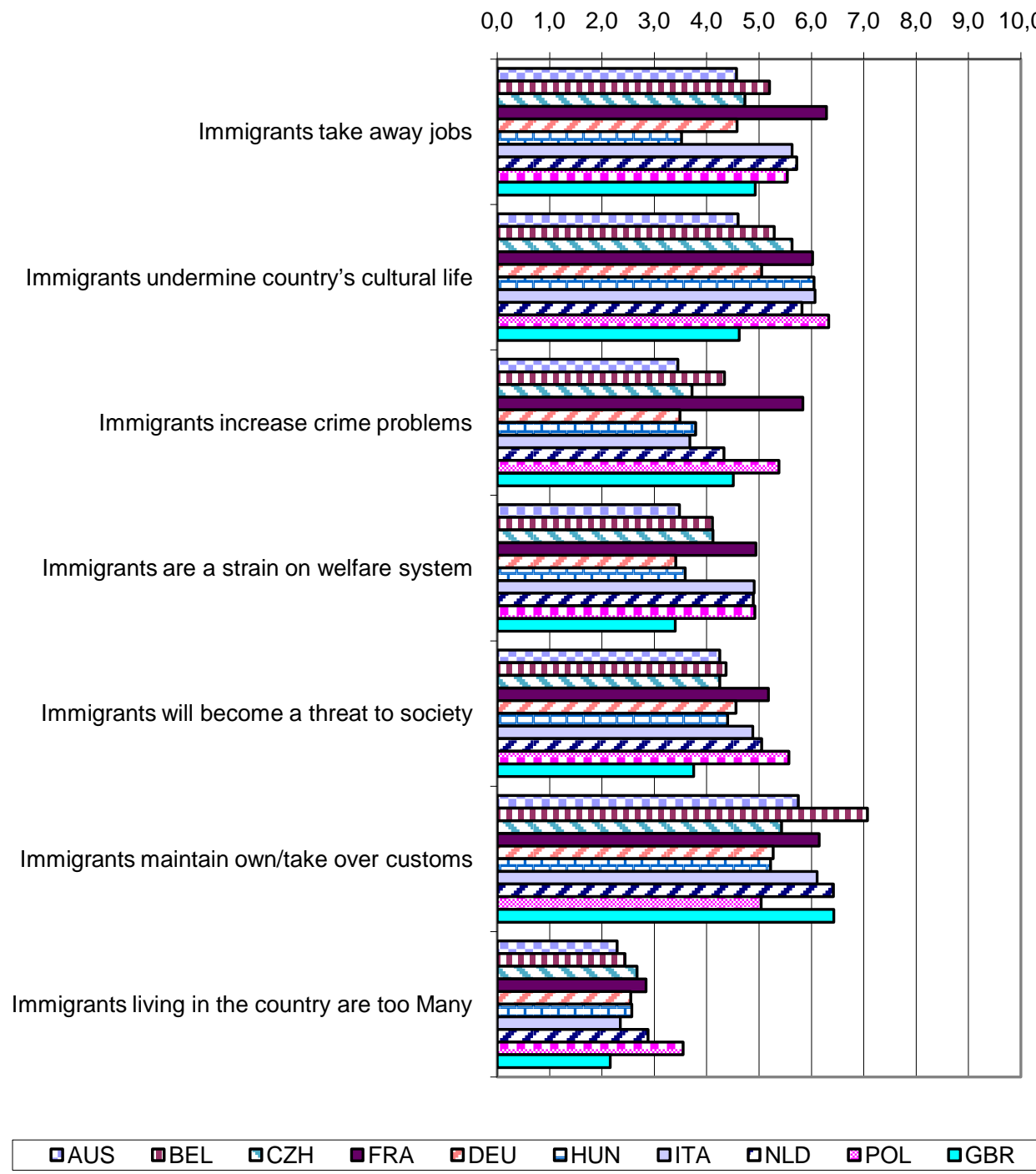

Figure 3

Attitudes towards immigrants in the Central and West European countries (Source: EVS (2011): European Values Study 1981-2008, Longitudinal Data File. GESIS Data Archive, Cologne, Germany, ZA4804 Data File Version 2.0.0 (2011-12-30), doi:10.4232/1.11005.)

The analysis of the data presented in Figure 4 on the perceptions of the immigrants in Southeast Europe shows a relatively similar picture. 


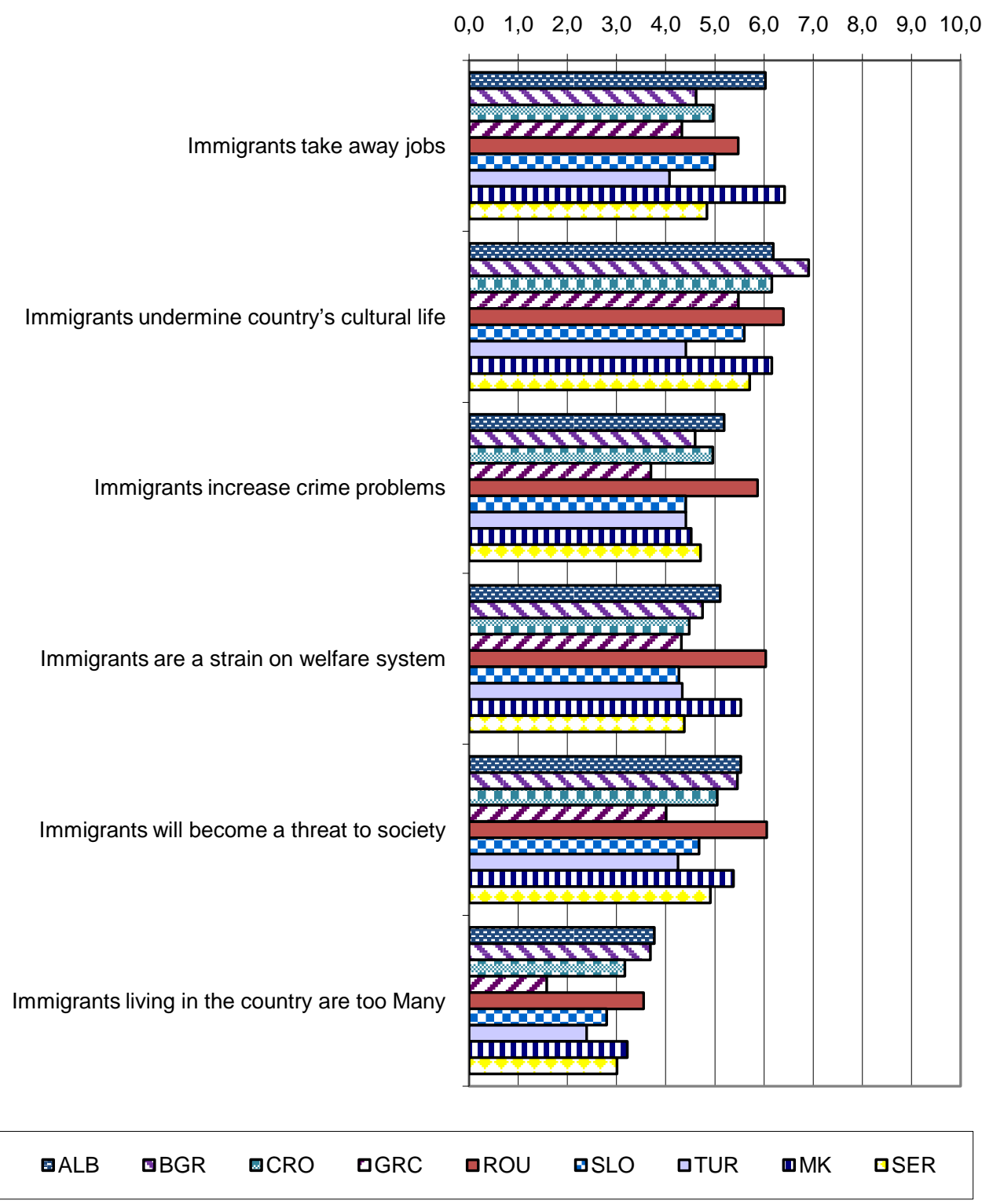

Figure 4

Attitudes towards immigrants in the Balkan countries (Source: EVS (2011): European Values Study 1981-2008, Longitudinal Data File. GESIS Data Archive, Cologne, Germany, ZA4804 Data File Version 2.0.0 (2011-12-30), doi:10.4232/1.11005.) 
There exists also a high level of support in Southeast European public opinion of statements like "Immigrants living in the country are too many", "Immigrants will become a threat to society", "Immigrants are strain on welfare system", "Immigrants increase criminal problems" and "Immigrants take away jobs". Indicative is the fact that almost all arithmetic mean values are below or close to 5.0. Compared with the perceptions of the West Europeans, there are no significant differences. Likewise, there is less fear in Southeast Europe regarding the threat to the national culture and customs. This is evident from relatively reduced amount of support for statements as "Immigrants undermine country's cultural life" and "Immigrants maintain own/take over customs", where the arithmetic mean estimates vary around 6.0.

In terms of perception of the number of immigrants in the countries concerned, the Southeast European public opinion is similarly unanimous that they are too many. The most worried are Greek people. The stereotypes about immigrants as a source of crime are strongest in Greece, followed by Slovenia and Turkey. Comparable are perceptions of the Bulgarians, Serbians, and Macedonians. Somewhat less negative are perceptions in Romania, Albania, and to some extent in Croatia.

As regards to the fear that immigrants will take over jobs, the analysis point out highest level of prejudice in Turkey and Greece, while the people in Macedonia, Albania and Romania are less worried. The Bulgarians, Croatians, Slovenians and Serbians demonstrate average level of concerns. The arithmetic mean value measuring the agreement of the respondents with this statement is close to 5.0. Concerning the perception of the threat to welfare system, most worried is public opinion in Slovenia, Turkey, Greece and Serbia. Comparatively less afraid are Romanians, Macedonians, Albanians, Bulgarians and Croatians.

Finally, there are significant differences among South East Europeans with respect to general perception that immigrants will become a threat to society. The strongest is the fear among the people in Greece, followed by Turks, Slovenians, Serbs and Croats. In the same time, Romanians, Albanians, Bulgarians and Macedonians demonstrate less prejudiced perceptions of immigrants.

On figure 5 data regarding views of the respondents from Central and Western Europe about the people from different race, Muslims, immigrants, and gypsies are presented.

Figure 6 presents data about opinions of respondents from the South Eastern Europe regarding ethno-cultural diversity in the society. In addition to above-mentioned categories of people, the group of "Christians" is added. 


\section{Securiaty}

The analysis of the data presented in Figure 5 reveals widespread negative attitudes towards Roma community in almost all countries of the Western and the Central Europe included in the study. The marginalization of Roma people is stronger in Italy and the Czech Republic, where correspondingly $58.6 \%$ and $48.0 \%$ of the citizens do not accept as a neighbor representative from this minority. In the UK, Belgium, Hungary, Poland and France over a third of the respondents do not accept as a neighbor one of Roma ethnic group. The prejudices towards Roma in Germany and Austria are comparatively less negative. Not-acceptance of the people from Muslim religious group as neighbors varies between $13.4 \%$ in France and $23.4 \%$ in Poland, while the average level of not-acceptance in the other West and Central European countries is about $20 \%$.

Similar are attitudes towards immigrants. The lowest is the level of not-acceptance of immigrants in France $-8.6 \%$ and the highest it is in the Czech Republic - 23.8\%.

The analysis of the attitudes of the respondents towards people from different race shows analogous results. The lowest is the level of not-acceptance in France $-6.6 \%$ and the highest it is in the Czech Republic - 18.8\%. 
Security

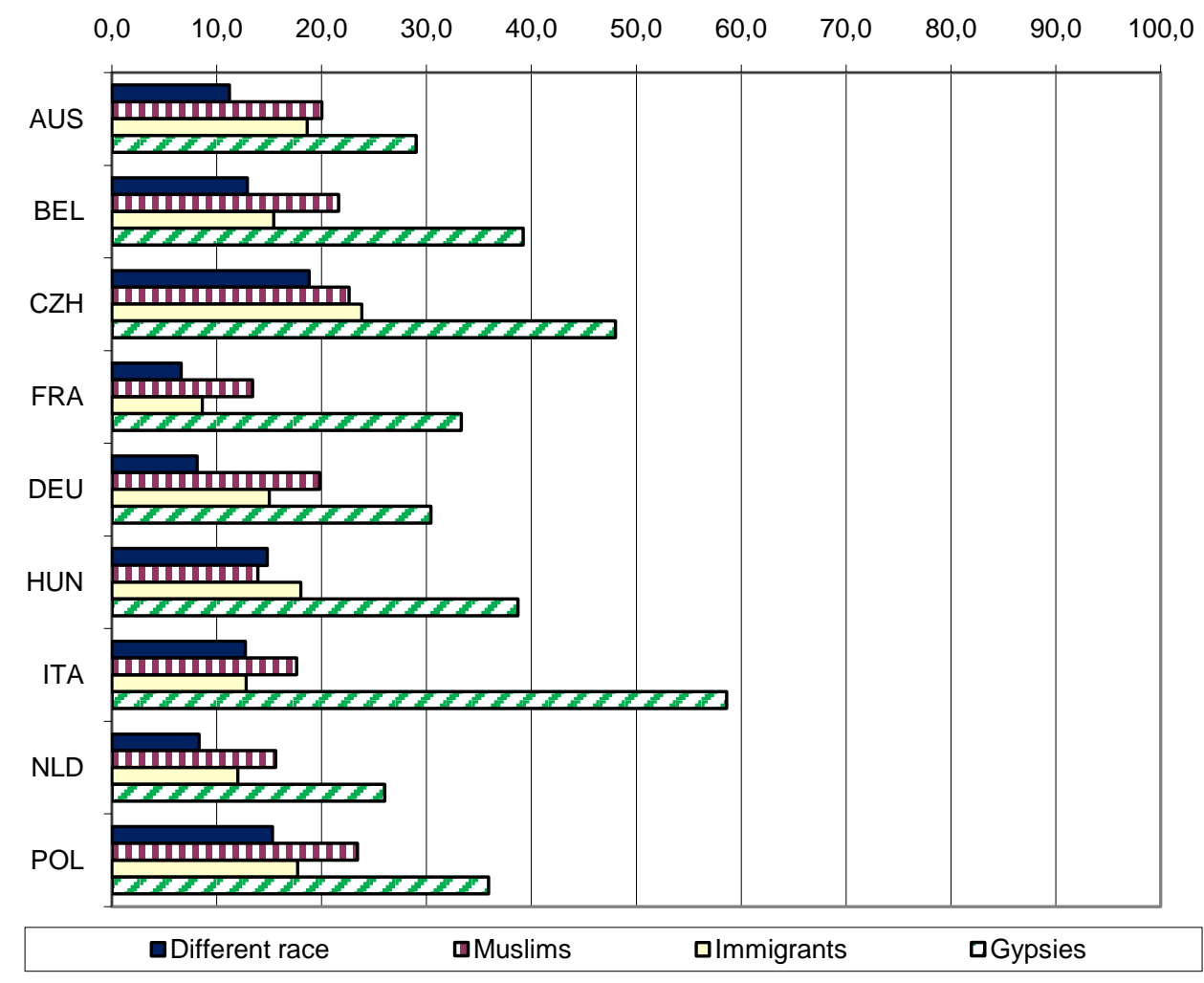

Figure 5

Distribution of positive answers to the question "I don't like as neighbors people from the following categories", Central and Western Europe, in percent (Source: EVS (2011): European Values Study 1981-2008, Longitudinal Data File. GESIS Data Archive, Cologne, Germany, ZA4804 Data File Version 2.0.0 (2011-12-30), doi:10.4232/1.11005.)

One can speculate that the respondents that do not accept as a neighbor representative from Muslim community, immigrants and/or people from different race are the same and they form a group. To confirm this hypothesis additional analysis is needed. The data presented in Figure 6 illustrates alike negative attitudes towards Roma community in the South East European societies. 


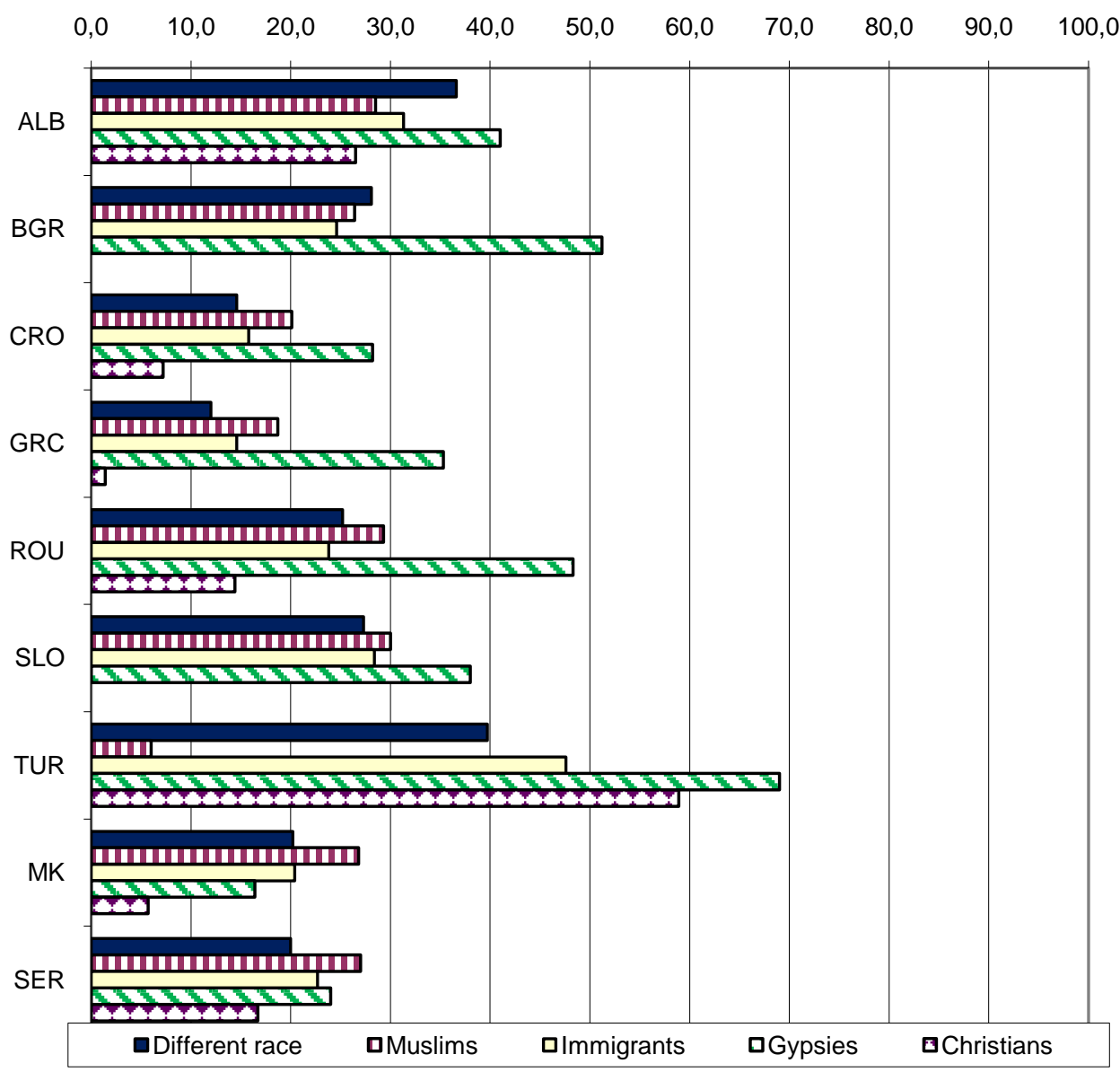

Figure 6

Distribution of positive answers to the question "I don't like as neighbors people from the following categories", South Eastern Europe, in percent (Source: EVS (2011): European Values Study 1981-2008, Longitudinal Data File. GESIS Data Archive, Cologne, Germany, ZA4804 Data File Version 2.0.0 (2011-12-30), doi:10.4232/1.11005.)

Note: In Bulgaria and Slovenia the question was not asked about "Christians".

The highest is the level of not-acceptance of the Roma people as neighbors in Turkey (69.0\%), followed by Bulgaria (51.2\%) and Romania (48.3\%). The prejudices towards Roma in Albania, Greece and Slovenia are comparatively less negative. Over a third of the respondents, correspondingly $41.0 \%, 35.3 \%$ and $38 \%$ in these countries do not accept as a neighbor one of the Roma community. The most tolerant are the attitudes towards Roma in 
Macedonia, Serbia and Croatia where less than one third of the respondents declare that they don't like as neighbors Roma people, respectively $16.4 \%, 24 \%$ and $28.2 \%$.

More than one - fourth of the respondents in Slovenia (30.0\%), Romania (29.3\%), Albania (28.5\%), Serbia (27.0\%), Macedonia (26.8\%) and Bulgaria (26.4) declare that they don't like to live in close vicinity with Muslims. A bit more positive are attitudes towards Muslims in Greece and Croatia, where respectively $18.7 \%$ and $20.1 \%$ of the respondents prefer not to have Muslims as neighbors.

On the whole, the perceptions of the respondents in South East Europe as regards people of different race are less positive in comparison to West European public opinion. Over a third of the citizens of Turkey (39.7\%) and Albania (36.6\%) state that they don't like as neighbors people from different race. More than one-fourth of the Bulgarians (28.1\%), Slovenians (27.3\%) and Romanians (25.2\%) maintain comparable attitude. Slightly more positive are the attitudes towards people from different race in Greece, Croatia, Macedonia and Serbia, where less than one-fifth of the respondents (between 12\% in Greece and 20.2\% in Macedonia) declare that that they don't like as neighbors such people.

The attitudes towards immigrants in the South East European countries vary significantly. The lowest is the level of not-acceptance of immigrants in Greece $-14.6 \%$ and in Croatia - 15.8\%, while the highest it is in Turkey - $47.6 \%$ followed by Albania - 31.3\%, and Slovenia $-28.4 \%$. In the rest of the countries presented in the survey the level of notacceptance of immigrants vary between one-fourth and one-fifth: $24.6 \%$ in Bulgaria, $23.8 \%$ in Romania, $22.7 \%$ in Serbia and $20.4 \%$ in Macedonia.

Finally, the analysis of the data presented on Figure 6 reveals high level of notacceptance of Christians as neighbors in Turkey (59.8\%) and Albania (26.9\%). Surprisingly, $16.7 \%$ of the respondents in Serbia and $14.4 \%$ in Romania also do not accept Christians as neighbors. Less than one-tenth of the citizens of Croatia (7.2\%) and Macedonia (5.7\%) maintain the same attitude. This fact deserves attention and needs deeper analysis to identify factors for the described perceptions.

Figure 7 presents data on attitudes of the citizens from 28 Member States of the European Union with regard to adoption of immigrants in the countryby two successive Eurobarometer surveys in 2014 and 2015.

The analysis of the data reveals diametrically opposed attitudes towards accepting immigrants in the EU, depending on whether these people come from other Member States, or from countries outside the Union. Just over half of the respondents (51\%) in the spring of 2015 express a positive attitude towards accepting immigrants from other EU countries, 
while $40 \%$ maintain negative attitudes and $9 \%$ have not formed a particular attitude. In terms of migration from outside the EU, the analysis of the data reveals contrasting attitudes. Only about a third (34\%) of the EU citizens is positive about such a perspective. The majority (56\%) have a negative attitude, while $10 \%$ are undecided.

The comparison of the attitudes of the Europeans on immigration, whether it comes to people from the other Member States or for people from countries outside the EU, remain almost unchanged compared to autumn 2014.

As far as these are the first results from Eurobarometer 83 and the data is still no available for secondary analysis, one cannot go deep to study the factors for the described perceptions. This will be a task for additional research in the future.

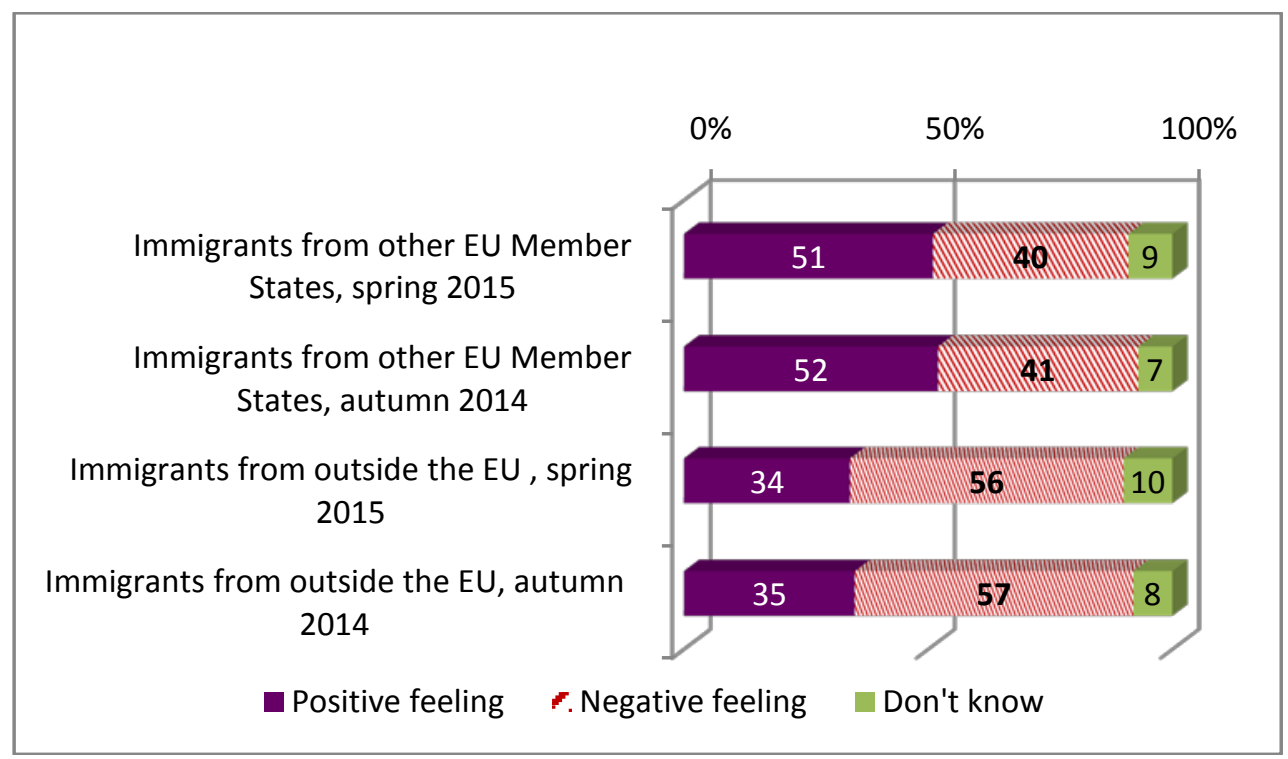

Figure 7

Public perceptions of the immigrants in the European Union, summary of data on the $28 \mathrm{EU}$ Member States, in \% (Source: Standard Eurobarometer 83, First results from spring 2015, available on http://ec.europa.eu/public_opinion /index_en.htm) 


\section{Conclusion}

The process of securitization of interethnic and interreligious relations, which become more and more relevant, especially after September $11^{\text {th }}, 2001$, is one of the major barriers to successful management of ethno-cultural diversity both in the Western and Southeastern Europe. This process will continue to be in the focus of attention of researchers and politicians who are called to make political decisions in the coming decades. This fact can easily be foreseen taking into account the processes of globalization, demographic and economic trends in the countries of the Middle East and North Africa and the associated greater than before migration. Europe will continue to be an attractive destination for large groups of people from these regions to flee from armed conflicts, instability and lack of economic prospects. For the time being, Europe remains divided between tolerance and prejudice against potential immigrants from outside the European Union. Outlined negative attitudes towards these people deserve special attention because they will become an important factor for successful implementation of effective policies for integration of immigrants in Europe, including Bulgaria. These attitudes can become fruitful bases for the escalation of extremist and radical ideas and establishment of social movements against the people who are different from us in terms of their race, ethnicity and culture. This is a challenging situation for European societies where much wisdom is necessary. We need cohesive social policies focused not only on cultural issues and ethnicity. They have to take into account the integration of the representatives of the traditional and the new minorities. The aim should be to achieve economic and political integration, as well as strengthening the value-normative identification of minority groups with the host society. Furthermore, these policies must be aimed at increasing cohesion in society, while preserving ethnic and cultural differences and identities. Last but not least, the requisite is to overcome the typical weakness of multiculturalism - the risk of ghettoization of minority groups, as well as the risk of their cultural assimilation.

\section{References}

1. Andreas Zick, Beate Küpper and Andreas Hövermann. "Intolerance, Prejudice, and Discrimination. A European Report". Friedrich-Ebert-Stiftung, International Policy Analysis, 2011. 
2. Buzan, B. andWæver, 0. Regions and Powers. The Structure of International Security, Cambridge (Cambridge University Press) 2003.

3. Cesari, J. The Securitization of Islam in Europe, Research Paper 15, April 2009. Centre for European Policy Studies. Available online on http://libertysecurity.org/IMG/pdf_The_Securitisation_of_Islam_in_Europe.pdf, accessed on 15.09.2014.

4. Vékony, Dániel"Potential threats of securitisation of Muslim minority politics in Western Europe". Biztpol affairs Vol. 2:2 2014.

5. EB 59.2 May - June 2003. Available from http://ec.europa.eu/COMMFrontOffice/PublicOpinion/index.cfm/Survey/getSurvey Detail/instruments/STANDARD/surveyKy/333.Accessed on 07.10.2015.

6. EVS (2011): European Values Study 1981-2008, Longitudinal Data File. GESIS Data Archive, Cologne, Germany, ZA4804 Data File Version 2.0.0 (2011-12-30), doi:10.4232/1.11005.

7. Flash EB 114, November 2001. Available from https://dbk.gesis.org/dbksearch/SDESC2_eng.asp?no=3603\&search=Flash\&search $2=\& D B=D$. Accessed on 07.10.2015.

8. Jocelyne Cesari, Chris Allen, Marcel Maussen, YaseminKarakasoglu, Sigrid Luchtenberg, Frank Peter, ReimSpielhous, Alexandre Caeiro, Jose Maria Ortuno Aix, MimaLiguori. Securitization and Religious Divides in Europe. Muslims in Western Europe After 9/11: Why the term Islamophobia is more a predicament than an explanation.Submission to the Changing Landscape of Citizenship and Security 6th PCRD of European Commission, 2006.

9. Kymlicka, W. Culturally Responsive Policies. Paper prepared for 2004 UNHDR Revised draft - June 15, 2004, United Nations Development Programme, Human Development Report Office, Background paper for HDR 2004.

10. Kymlicka. W. "Multiculturalism and Minority Rights: West and East", Journal of Ethnopolitics and Minority Issues in Europe, Issue 4/2002.

11. Lesińska, Magdalena."The European backlash against immigration and multiculturalism". Journal of Sociology, 2014, Vol. 50(1) 37-50, SAGE.

12. Rex, J. and G. Singh. "Multiculturalism and Political Integration in the Modern National States - Thematic Introduction".International Journal on Multicultural Societies (IJMS), Vol. 5, No 1, 2003, 3-19. 
13. Roe, P. "Securitization and Minority Rights: Conditions of Desecuritization". In: Security Dialogue, Vol. 35, 3 / 2004, pp. 279-294.

14. Roudometof, V. National Minorities, Nation-states, and External National Homelands in South Eastern Europe". In: The New Balkans: Disintegration and Reconstruction, Kourvetaris G., Roudometof V., Koutsoukis K. and Kourvetaris A. (Eds.), Columbia University Press, New York, USA, 2002, 55-84.

15. Standard Eurobarometer 83, First results from spring 2015, available on http://ec.europa.eu/public_opinion/index_en.htm, accessed on 10.09.2015.

16. Thorsten G. \& Thorsten B. The Concept of Securitization as a Tool for Analyzing the Role of Hunan-Rights-Related Civil Society in Ethno-Political Conflicts, SHUR WP 05/07, March 2007. Available online on http://shur.luiss.it/files/2008/10/shurwp05-07.pdf, accessed on 15.09.2014.

17. Zuhal Yesilyurt Gündüz. Europe and Islam: No Securitization, Please! FriedrichEbert-Stiftung, International Policy Analysis, 2007. 